\title{
The Effect of Cassava Leaf Extract Additional in Antioxidant Activity and Fe Content of Wet Noodle
}

\author{
Novelina ${ }^{\#}$ \\ ${ }^{\text {\# }}$ Faculty of Agricultural Technology, Andalas University, Indonesia, 25163 \\ E-mail:novelinasutanto@yahoo.com
}

\begin{abstract}
Cassava leaf contains vitamin, mineral, fiber, chlorophyll, and calorie. The vitamin which is found in cassava leaf are vitamin A, B1, B2, C, niacin, and also mineral like Fe (iron), Ca (Calcium) and P (Phosphorous). In $100 \mathrm{~g}$ of cassava leaf contains $2 \mathrm{mg}$ of iron, this amount enough to fulfill iron needed by human body. Iron plays the important role in a human body to carry the oxygen from lungs to the tissue and to carry the electron in the process of performing energy in the cell. This research is aim to see the influence of addition of cassava leaf extract to the activity of antioxidant and iron content of wet noodle produced. The treatment in this research is addition level of cassava leaf extract in the wheat compound dough for the preparation of wet noodle. The result showed that addition level of cassava leaf extract increased the activity of antioxidant up to $54.38 \%$ and iron content up to 27.43 ppm.
\end{abstract}

Keywords - cassava leaf; cassava flour; wet noodle; antioxidant; iron

\section{INTRODUCTION}

The usage of cassava leaf is wider, both for vegetables and medicine. The average of vitamin and mineral content of cassava leaf are higher than other vegetables. Vitamin A and $\mathrm{C}$ in cassava leaf are having a role as antioxidant which can prevent the aging process and increase body endurance from the disease. According to [1] content of $\beta$-Carotene cassava leaf processed is 19.022 - $79.543 \mu \mathrm{g} / \mathrm{g}$ ), depend on processing method. Leaf of cassava rich of Fe. One of the important mineral for the health of body is Fe. Deficiency of $\mathrm{Fe}$ is a major cause of anemia for pregnant women in Indonesia where its prevalence is highly enough so that still become main problem of society health [2].

It is time now to think on how to make a change of conventional food serving of cassava leaf in order to make the product follow the trend of current food serving, where the food serving are practical and interesting, such as noddle, since noodle is the popular product in the world. In Indonesia, noodle becomes the main alternative food after rice. According to Indonesian Commercial Newsletter, in 2007 and 2008 production of instant noodle reached 1.443.686 tons/year and 1.544.072 tons/year which is $7.7 \%$ increased [3]. The rapid increasing production of noodle in Indonesia gives the figure that noodle is suitable food for our need, hence we need to make new innovation of "healthy noodle" the noodle made from vegetables and natural food coloring without adding the addictive essence like a noodle with using cassava leaf extract's substitution.

Cassava flour is being mass-produced, but its application in the food industry is not optimized yet. Generally, cassava flour is only being used as thickener or additive in the cake making process, not as a main ingredient. There are three basic differences between cassava flour and wheat flour. First of all, cassava flour doesn't contain any gluten. Gluten is a protein compound in wheat flour that gives elasticity and extensibility in noodles. Secondly, according to [4] has found that, compared to other starches, cassava starch contains more amylopectin (87\%) than amylase. Amylopectin has a higher viscosity than amylase, resulting in stickiness and a higher viscosity in cassava starch. Last but not least, cassava also contains cyanogen compounds, which have to be removed prior to the cassava being used as a food ingredient.

Other than flour, some basic ingredients of noodles are: water, egg, salt, and alkali. The flour is the carbohydrate source. The dough consists of matrixes that are formed from flour and water. Salt is added to flavour the noodle, but it can also strengthen the structure, increase the elasticity and flexibility, in addition to bonding with water. Egg basically provides nutritive value to the noodles and the ability to not break easily. The egg-white can produce a thin and strong layer on the noodles surface. Egg-yolk consists of lecithin, which is widely known as a good emulsifier. Alkali water or q-water is used in noodle making; the purpose of the addition of alkali is to increase the elasticity and 
extensibility, and to soften the noodle's texture. Alkali can release $\mathrm{CO} 2$, causing the dough to expand. The usual alkali compounds that are used in noodles are: sodium carbonate, potassium carbonate, and phosphoric salt. The alkali dosage in noodles is $0.5-0.6 \%$ flour weight [5].

The cassava flour can be the alternative product to substitute the wheat flour. The result of related literature makes a fruity noodle with wheat flour using cassava flour and tamarillo extract's substitution. In previous research the best result of substitution of wheat flour with cassava flour is $20 \%$ [6]. This research is aimed to see the effect of the addition of cassava leaf extract on the antioxidant activity and Fe content of wet noodle.

\section{MATERIAL AND METHOD}

\section{A. Material and Equipment}

The material that used in this research are wheat flour, cassava flour, cassava leaf, salt, water, $\mathrm{KSCN}, \mathrm{FeCl}_{3}, \mathrm{H}_{2} \mathrm{SO}_{4}$ concentrated, selenium mix $30 \% \mathrm{NaOH}$ solution, $\mathrm{H}_{3} \mathrm{BO}_{3}$ solution, HCL solution, anti-bumping granules, DPPH and methanol, while the equipment are plastic containers, spoon, blender, plastic, spectrophotometer, oven and Kjeldhal flasks, analytical balance oven, desiccator, hot plate, dry ashing, burette, Erlenmeyer, cup nipper, glass stuff, pH meter, etc.

\section{B. Experimental Design}

This research conducted with Completely Randomized Design (CRD) with five treatments and three observations. The treatment are percentage of cassava leaf extract to replace water in the preparation of wet noodle, as follows : A $=100 \%$ cassava leaf extract $\mathrm{B}=80 \%$ cassava leaf extract; $\mathrm{C}$ $=60 \%$ cassava leaf extract $; \mathrm{D}=40 \%$ cassava leaf extract; $\mathrm{E}$ $=0 \%$ cassava leaf extract. The data are analysed statistically with F test and Duncan's New Multiple Range Test (DNMRT).

\section{Observation}

The observation of this research are analysis of Fe content with spectrophotometric methods [7], antioxidant activity using DPPH methods [8]. water content (gravimetric methods), ash content; protein content semi-micro Kjeldahl methods [9] and sensory evaluation.

\section{Iron content}

Analysis of $\mathrm{Fe}$ started making of the calibration graph use Thiocyanate spectrophotometry principle, and then preparation of sample with ashing process. Ashing of the samples: 1-15 $\mathrm{g}$ of the edible portion of the food samples was weighed. They were finely chopped for the purpose of ashing. The weighed samples were finely chopped and heated in a stainless steel vessel over a hot induction plate at $200-240^{\circ} \mathrm{C}$. This step was carried out in a well-ventilated room. The heating time varied depending on the amount of sample and the rate at which the sample burned to ash. The samples were heated till a grayish ash was observed and then they were powdered using a mortar and pestle. After the samples were cooled, they were transferred to a small beaker of $100 \mathrm{ml}$ capacity and the iron (III) in the ash was dissolved in $10 \mathrm{~mL}-30 \mathrm{ml}$ of $2 \mathrm{M} \mathrm{HCl}$. The ash solution was stirred using a glass stirring rod for about 5 minutes and then filtered.

Analysis of the samples: $5 \mathrm{ml}$ of the filtered sample was transferred to a test-tube and then $5 \mathrm{ml}$ of $1.5 \mathrm{M} \mathrm{KSCN}$ was added. The mixture was stirred by swirling the test tube. The absorbance was measured without delay as the color of the solution faded within 15-20 minutes. The solution concentration was halved by adding $5 \mathrm{ml}$ of $\mathrm{KSCN}$, thus, the concentration values were multiplied by 2 during the calculations. The $2 \mathrm{M} \mathrm{HCl}$ solution served as the blank. The absorbance values were measured for all samples. The absorbance values were determined by the spectrophotometer and the concentration was found out by interpolation or extrapolation using the calibration graph prepared earlier. After the calculations, the iron content determined in the different food samples was tabulated in an increasing order of amount of iron [7].

\section{E. DPPH radical scavenging activity}

DPPH radical Scavenging Activity (DPPHRSA), total polyphenols, scavenging activity was determined using the method originally developed by [8]. A portion $(0.1 \mathrm{ml})$ of the extract solution $(1.0 \mathrm{mg} / \mathrm{ml}$ methanol $)$ in a test tube was well mixed with $3.9 \mathrm{ml}$ of methanol and $1.0 \mathrm{ml}$ of a DPPH solution (1.0 mM in methanol). The mixture was kept at ambient temperature for $30 \mathrm{~min}$ prior to measurement of the absorbance at $517 \mathrm{~nm}$ (A517 $\mathrm{nm})$.

All measurements were done in triplicate:

$$
\text { DPPH-RSA }(\%)=\frac{\text { (control absorbance-extract absorbance) }}{\text { control absorbance }} \times 100
$$

\section{F. Protein content}

The crude protein was determined by the Kjeldahl method with slight modification. $0.5 \mathrm{~g}$ of the sample wet noodle digested with $5 \mathrm{ml}$ of concentrated sulphuric acid in the presence of Kjeldahl catalyst. The nitrogen from the protein in the sample was converted to ammonium sulphate that reacted with $2.5 \mathrm{ml}$ of $2.5 \%$ Brucine reagent, $5 \mathrm{ml}$ of $98 \%$ sulphuric acid to give a colored derivative and the absorbance read at $470 \mathrm{~nm}$. The percentage nitrogen was calculated and multiplied by 6.25 to obtain the value of the crude protein [9].

\section{RESULT AND DISCUSSION}

\section{A. Iron Content}

Iron $(\mathrm{Fe})$ is a mineral which is needed to form hemoglobin. Moreover, mineral also has a role as the component to form myoglobin (protein which is found in a bone, cartilage, and connective tissue), and also enzyme. Iron also has a function in body defense system [10]. Consuming iron daily is needed to replace the missing iron through feces, urine and skin. Losing of this dropsy about 14 $\square \mathrm{g} / \mathrm{kg}$ of weight or almost same as $0.9 \mathrm{mg}$ iron in adult man and $0,8 \mathrm{mg}$ in adult woman. One of guidance to complete the iron needed is organizing the balance diet model based on food pyramid so that the macronutrient and micronutrient can be completed [10].

The total body iron in a $70-\mathrm{kg}$ man is about $4 \mathrm{~g}$. This is maintained by a balance between absorption and body losses. Although the body only absorbs $1 \mathrm{mg}$ daily to maintain 
equilibrium, the internal requirement for iron is greater (20$25 \mathrm{mg}$ ). An erythrocyte has a lifespan of 120 days so that $0.8 \%$ of red blood cells are destroyed and replaced each day. A man with $5 \mathrm{~L}$ of blood volume has $2.5 \mathrm{~g}$ of iron incorporated into the haemoglobin, with a daily turnover of $20 \mathrm{mg}$ for haemoglobin synthesis and degradation and another $5 \mathrm{mg}$ for other requirements [11].

The result of research shown that the more adding of cassava leaf extract, the more content of $\mathrm{Fe}$ in wet noodle increase. Fe content approximate $9.80-27.43$ ppm indicated that increasing of Fe content in wet noodle influenced by the adding of cassava leaf extract amount in wet noddle, which can be seen in Fig. 1.

The highest Fe content in wet noodle found at treatment A where wet noodle added with $100 \%$ of cassava leaf extract, while the lowest $\mathrm{Fe}$ content resulted from treatment $\mathrm{E}$ which is wet noodle without adding cassava leaf extract. Besides, Fe content can be obtained from wheat flour and cassava flour.

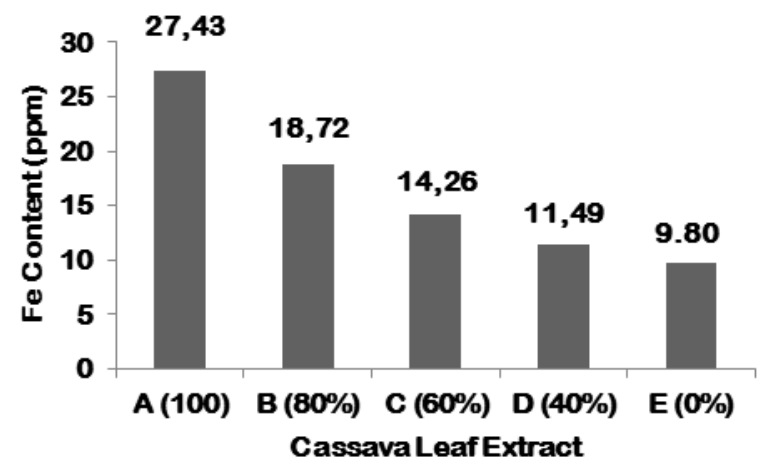

Fig. 1. Graphic of Fe Content in Wet Noodle

The increasing of iron (Fe) mineral in food is better than giving the Fe orally, because giving the Fe orally can cause an effect in gastrointestinal in some people, like feels uncomfortable in liver, nauseous, vomiting, and diarrhoea. The frequency of this effect is related to the dosage of iron. The iron which is consumed will be tolerated better in spite of the amount of iron which is absorbed decrease. The giving of Fe supplement preparation some women, can cause constipation, to overcome it the women should adds the consumption of the food with rich of fiber like bread, cereal and gelatine [12].

It is estimated only $5-15 \% \mathrm{Fe}$ absorbed from food by adult human with good status of $\mathrm{Fe}$ in their body. While in $\mathrm{Fe}$ deficiencies status absorbing can reach 50\%. Type of $\mathrm{Fe}$ in food have effect on the absorbing. Fe-heme as part of haemoglobin and myoglobin found in animal meat absorbed twice compare to $\mathrm{Fe}$ non-heme. At least $40 \% \mathrm{Fe}$ in meat, chicken and fish are Fe-heme and the rest as non-haem. Fe non-heme also found in egg, cereal, nuts, green vegetable and some of fruits. Consuming Fe-heme and non-heme together will increase absorbing on of Fe non-heme [13].

The least iron was available in the local vegetables. An extremely high quantity of iron was observed in cumin seeds and bay leaves, which are whole spices, regularly accompanied with food as seasonings to enhance the taste of meals served in India. Vegetarians are usually susceptible to low iron intake as they are dependent on non-heme sources of iron, which are not readily absorbed and they do not usually contain the large amount of iron as is offered by the meat or heme sources. Vegetarians may improve their dietary iron intake, according to the Recommended Daily Intake (RDI) of iron, by following a diet containing iron-rich vegetarian food sources like green leafy vegetables (spinach), nuts, pulses (lentils and kidney beans) [5].

Success fortifying with $\mathrm{Fe}$ as a public health intervention depends on several factors including: adequate legislation and regulations, monitoring and enforcement and then consumption of fortified foods in sufficient amounts [14].

\section{B. Antioxidant Activity}

The graphic of antioxidant content in wet noodle can be seen in Fig. 2 The more adding percentage of cassava leaf extract, the more antioxidant activity happened. Cassava leaf contains of vitamin A and C, 100g of cassava leaf contains of 3.300 RE vitamin A which is very good for eyes health and $275 \mathrm{mg}$ of vitamin C [15]. Afterwards, the high of antioxidant in wet noodle also influenced by the chlorophyll content of cassava leaf.

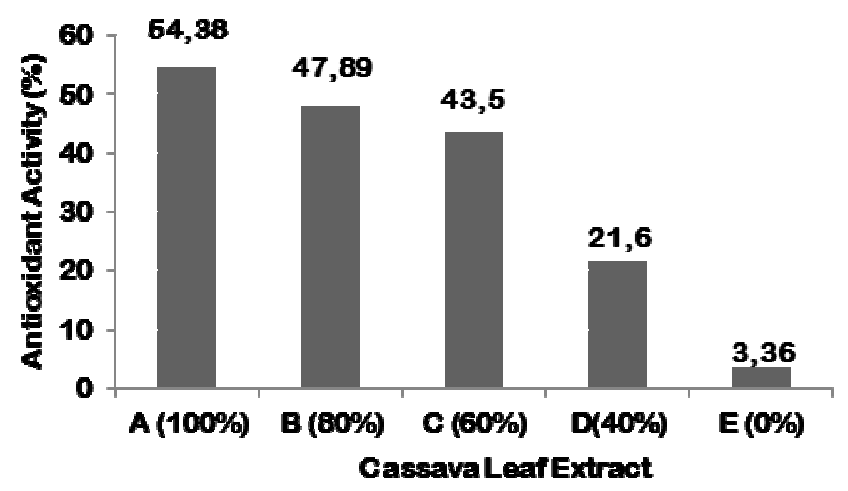

Fig. 2 Graphic of Antioxidant Activity in Wet Noodle

Based on previously research report known that the highest chlorophyll content of 10 vegetables and 2 kinds of grass obtained in cassava leaf extract at $3.967 \mu \mathrm{g} / \mathrm{g}$ [16]. Chlorophyll content of cassava higher of grass jelly leaves (Premna oblongifolia Merr.), total chlorophyll concentrated grass jelly leaves have $1184.475 \mu \mathrm{g} / \mathrm{g}$ [17].

Chlorophyll has an ability to catch the DPPH radical. Chlorophyll will react with peroxide radical ROO* which is produced in the beginning phase of oil oxidation and change into $\pi$-cation radical from the chlorophyll which is bundled with negative peroxide radical with loose bundle and make a complex which is has an intermediate attribute. This complex afterwards reacts with the other peroxide radical and finally makes an inactive product. Therefore, the more adding of cassava leaf extract in the dough of wet noodle, so the chlorophyll which is produced will be more high and also makes a high antioxidant activity [18].

The information about the antioxidant activity will give an understanding for change the habitual to consume no polished rice cultivar. DPPH (1.1-diphenyl-2picrylhydrazyl) causes a deep violet color with around $520 \mathrm{~nm}$. When a solution of DPPH is mixed with a substrate acting as hydrogen atom donor, a stable non radical form of DPPH is 
obtain with simultaneous change of the violet color to pale yellow [19].

Chlorophyll is bio-active compound which also can be extracted from microalgae. This chlorophyll commonly used as food colorant and have functioned as antioxidant of antimutagenic. Some of crops type and phytoplankton have been used as food materials where some of chemicals content often eliminated, including chlorophyll. Although chlorophyll can increase metabolic function in the body, since chlorophyll is compound of natural antioxidant found in organism of photosynthetic [20,21].

\section{Water Content}

Water is an important basic element in foods. For a long time, the industry has known how important it is to check free water. The moisture and water activity measurement forms the basis of this and provides important information about the quality of a product. Finally it provides information regarding the possibility of microbiological growth on the surface. Only with this conclusions can be made about the stability and durability of perishable product (wet noodle). Free water in products is jointly responsible for the growth of undesirable organism such as bacteria or fungi, which produce "toxins" or other harmful substances.

The result of analysis in Table 1 shown that the water content among treatments at the range of 32.71-35.04\%. According standard of quality SNI 2987:2015 [22] water content of wet noodle is $20-35 \%$. Result from this research that water content of wet noodle obtained in the range of the standard mentioned. The more adding the cassava leaf extract on wet noodle influenced on water content. The more adding of cassava leaf extract the lower the existence of unbound water in a noodle dough and conversely since in cassava leaf contains of the components such as protein, mineral and vitamin. Protein and fiber contain of much hydrophilic cluster which can bind water. The more protein and fiber in wet noodle make the hydrophilic cluster increases so that cause the water content decreases.

TABLE I

\begin{tabular}{|c|c|c|c|}
\hline \multirow{2}{*}{$\begin{array}{l}\text { Addition of } \\
\text { cassava leaf } \\
\text { extract }\end{array}$} & $\begin{array}{l}\text { Moisture } \\
\text { Content }\end{array}$ & $\begin{array}{l}\text { Ash } \\
\text { Content }\end{array}$ & $\begin{array}{l}\text { Protein } \\
\text { Content }\end{array}$ \\
\hline & \multicolumn{3}{|c|}{ (\%) } \\
\hline A (100\%) & $32.71 \quad \mathrm{c}$ & $1.08 \mathrm{a}$ & $10.50 \mathrm{a}$ \\
\hline B (80\%) & $33.29 \quad \mathrm{bc}$ & $0.72 \quad b$ & 9.22 \\
\hline $\mathrm{C}(60 \%)$ & 33.81 b c & 0.65 & $8.41 \quad b c$ \\
\hline $\mathrm{D}(40 \%)$ & $34.16 \mathrm{ab}$ & 0.49 & 7.35 \\
\hline $\mathrm{E}(0 \%)$ & $35104 \mathrm{a}$ & 0.47 & 6.65 \\
\hline CV (\%) & 1.31 & 15.88 & 4.68 \\
\hline
\end{tabular}

Numbers followed by the same lowercase, not significantly different at the $5 \%$ significance level

\section{Ash Content}

The average ash content analysis in wet noodle can be seen in Table 1. Compare to the standard of SNI 2987:2015 [22] maximum ash content in wet noodle is $3 \%$. Wet noodle with the adding of cassava leaf extract qualifies of SNI- SNI
2987:2015 [22]. Ash content in wet noodle which is added by cassava leaf extract is approximate around 0.46-1.08\%. The ash content of wet noodle influenced by the mineral of cassava leaf. According to [15], cassava leaf contains some important mineral needed by the body, such as $\mathrm{Ca}(165$ $\mathrm{mg} / 100 \mathrm{~g}), \mathrm{P}(54 \mathrm{mg} / 100 \mathrm{~g})$ and $\mathrm{Fe}(2 \mathrm{mg} / 100 \mathrm{~g})$.

The height of calcium content in cassava leaf is very helpful to construct the bones and teeth in human. The function of phosphorous similar with calcium for constructing the bones and teeth and also for saving and spending the energy (the changes between ATP and ADP). DNA and RNA are consist of phosphorous in phosphate form, and also the cells membrane which are help to keep cell permeability. Magnesium is the activator of peptidase enzyme other enzyme which its function breaking and transferring phosphate cluster (phosphatase). The other mineral which is also important is iron. Iron in the body located inside haemoglobin as haem, a pigment which is contains of an atom of $\mathrm{Fe}$ [23].

\section{E. Protein Content}

The result of analysis of protein content in Table 1 shown that the more adding of cassava leaf extract, the more protein content in wet noodle increase. This is because of protein content in wet noodle influenced by the protein content of cassava leaf, where protein content of cassava leaf is $6.8 \%$.

The minimum protein content of wet noodle according to Indonesian standard SNI 2987: 2015 [22] 3\% minimum based on the calculation dry material. Result from research protein content of wet noodle in the range of $6.65-10.5 \%$ so that meet with standard [22]. The adding of cassava leaf extract into the dough of wet noodle which is aimed to give the innovation in making the wet noodle not only to support food diversification but also to increase protein content in wet noodle.

Quality of noodles depends largely on flour characteristics and on conditions used during noodle preparation because noodles are generally prepared from wheat flour, water, and salt through mixing, sheeting, and cutting processes. There has been little information regarding the protein characteristics requirements of wheat for production of white salted noodles, although protein quality as related to bread baking has been extensively studied and well established. The evaluation of protein characteristics related to noodle making can help to develop wheat cultivars suitable for white salted noodles in breeding programs. Wheat flour with around $10 \%$ protein content is acceptable for making white salted noodles.

Protein content of flour is another important factor that affects the brightness by increasing the whiteness of both the flour and fresh noodles with decreasing amounts of protein in the flour. This effect is however not significant once the noodles are cooked. Protein content also affects the texture and quality of noodles because it has a positive and negative correlation with noodle toughness and oil uptake respectively [5].

\section{F. Sensory evaluation}

The sensory evaluation which is undertaken using hedonic test on color, aroma, taste and texture from the wet noodle product in the amount of panelist are 20 persons and the 
assessment score are from 1 until 5. The average value of panellist assessment regarding the color, aroma, taste and texture of wet noodle product added by cassava leaf extract can be seen at Table 2 .

TABLE II

The Average Value Of Panelist Assesment On Wet Noodle PRODUCT

\begin{tabular}{|l|c|c|c|c|}
\hline \multirow{2}{*}{$\begin{array}{c}\text { Addition of } \\
\text { cassava leaf } \\
\text { extract }\end{array}$} & \multicolumn{4}{|c|}{ The average value of panelist assessment } \\
\cline { 2 - 5 } & Color & Aroma & Taste & Texture \\
\hline $\mathrm{A}(100 \%)$ & $3.40 \mathrm{a} \mathrm{b}$ & $2.30 \mathrm{~b}$ & $2.50 \mathrm{~b}$ & $2.55 \quad \mathrm{c}$ \\
\hline $\mathrm{B}(80 \%)$ & $3.50 \mathrm{a}$ & $2.40 \mathrm{~b}$ & $2.65 \mathrm{~b}$ & $2.65 \mathrm{~b} \mathrm{c}$ \\
\hline $\mathrm{C}(60 \%)$ & $3.70 \mathrm{a}$ & $3.35 \mathrm{a}$ & $3.70 \mathrm{a}$ & $3.25 \mathrm{a}$ \\
\hline $\mathrm{D}(40 \%)$ & $3.55 \mathrm{a}$ & $3.20 \mathrm{a}$ & $3.65 \mathrm{a}$ & $3.10 \mathrm{ab}$ \\
\hline $\mathrm{E}(0 \%)$ & $2.80 \mathrm{~b}$ & $3.05 \mathrm{a}$ & $3.50 \mathrm{a}$ & $3.10 \mathrm{ab}$ \\
\hline
\end{tabular}

Numbers followed by the same lowercase, not significantly different at the $5 \%$ significance level. Description : $1=$ really dislike , $2=$ dislike, $3=$ normal , 4 $=$ like, $5=$ really like

1) Color: Color is an important factor in our daily lives as consumers are surrounded by an infinite variety of colors. Color strongly affects our preference for various items in our environment. Aside from texture, color is another most important aspect of noodle attributes since it is the first to be perceived by the consumers. In the wet noodles however, color tends to have a different significance compared to texture because wet noodles have high moisture content therefore it is unstable [5]. All noodle types require good brightness. Color can be either white or yellow depending on the absence or presence of alkali salts. Minimal noodle darkening within 48 hours is desirable. This may not be a problem for the instant noodles because they are dried and the color is very stable. The adding of cassava leaf extract makes the wet noodle green (Fig. 3), so the receiving level of panellist regarding color tend to like. The average value of color for wet noodle is in the like categories except in E treatment which is exist in the dislike categories. According to [23], the color factor is an important thing to determine the quality of the foodstuffs beside the taste, texture and nutrient. The foodstuffs which is in a good nutrition, delicious and good texture, sometimes are disliked if is not interesting or does not give the good impression.

2) Aroma: Cassava leaf extract which has added, gives a special aroma so that the variation of giving cassava leaf extract is influences the aroma of noodle. Generally, the aroma which is received by nose and brain are the mixture of four main aroma such as fragrant, acid, stale and overcooked. In chemically, it is hard to explain why the compounds cause a different aroma, because the compounds which have a chemical structure and almost similar functional cluster (stereoisomer) sometimes have very different aroma.

3) Taste: The taste of the noodles is affected by the particle size and the quality of the flour. Flour is the main component of the noodles, about $54 \% \mathrm{w} / \mathrm{w}$ of the dough. The cassava flour has been through a fermentation process that eliminates the real taste of cassava, so its application in noodle making should be similar to that of wheat flour. The particle size of the cassava flour, however, is still relatively big and hence gives the noodle a sandy feeling in the mouth. The result of assessment to the taste in Table 2, shown that the taste among treatments are significant and its located in the range of 2.50-3.70. It observed there is trend that the more adding of cassava leaf extract, so the assessment of taste decrease. The significant of panellist caused by the more adding of cassava leaf extract which is cause a bitter taste. Each person has the lowest limit of concentration to the taste in order to be tasted. This limit is called as threshold and not same for everyone. The other taste component will interact with the primary component taste. The effect which is appeared may increase or decrease taste intensity. The interaction effect is different at the level of concentration and its threshold [23].

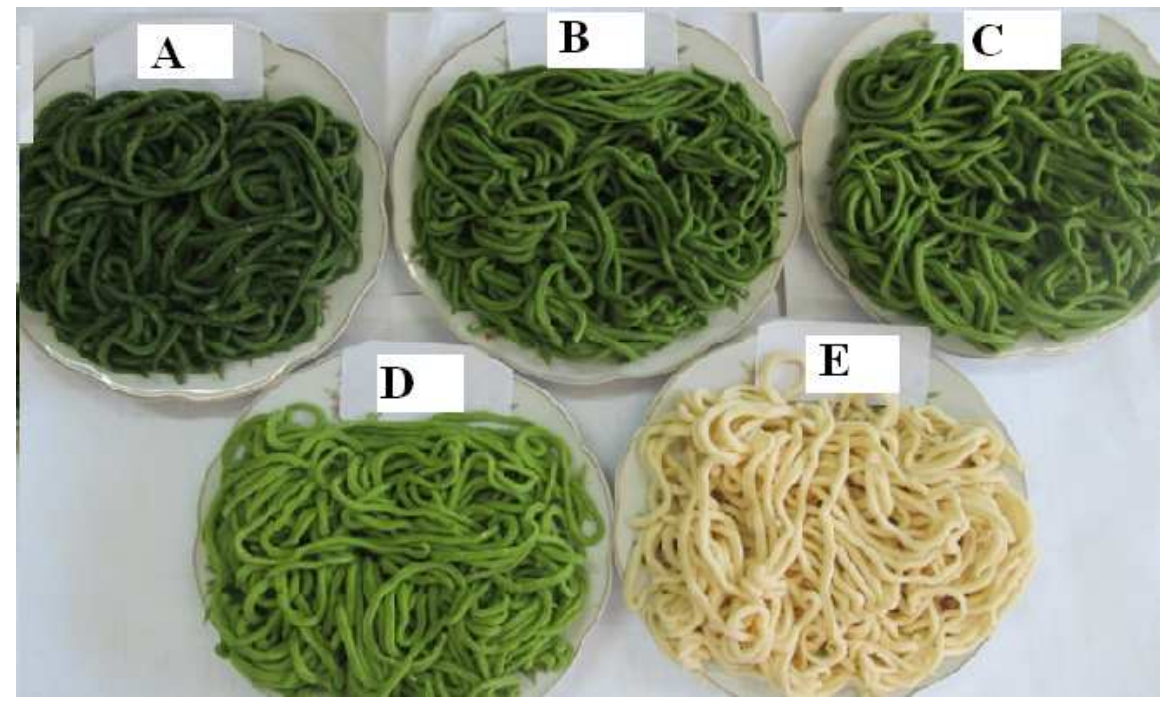

Fig. 3 The colors wet noodle of treatment 
4) Texture: The most affecting components for the noodle's texture are egg, vegetable oil, gluten and alkali water. Egg white produces a thin but strong layer on the noodle's surface, which makes it not break easily. Egg yolk contains lecithin, which is a good emulsifier. Lecithin is a surfactant that consists of fosfodic acid, choline, fatty acid, glycerol, glycolipid, triglseride, and phospholipid. Lecithin can reduce the surface tension of the water to emulsified fat. Lecithin also reduces the surface tension between these two liquid components by absorption at the meeting point. The assessment of texture in Table 2, shown that the average value which is given by the panelist regarding the wet noodle texture is exist in the category of dislike until almost like around 2.55-3.25. The result assessment of panelist can be concluded that the more adding cassava leaf extract in wet noodle, the low assessment of texture in wet noodle. Overall, the average result of organoleptic assessment for all treatments are exist in almost like category, except in A treatment. The addition of cassava leaf extract excessively in making wet noodle can make the panellist dislike of A product for aroma, taste and texture. Based on the result of organoleptic test concluded that adding cassava leaf extract for making wet noodle is $60 \%$ (treatment $\mathrm{C}$ ).

\section{CONCLUSIONS}

Based on the result of research concluded that wet noodle with the addition of $60 \%$ of cassava leaf extract is the best product based on organoleptic and has good nutrition content. The result of the test from product $\mathrm{C}$ obtained $14.264 \mathrm{ppm}$ of Fe content, $43.503 \%$ of antioxidant activity, $33.807 \%$ of water content, $0.65 \%$ of ash content, $8.406 \%$ of protein content. and average value of preference 3.5 (like).

\section{REFERENCES}

[1] Meiliana, Roekistiningsih, Sutjiati E. Pengaruh Proses Pengolahan Daun Singkong (Manihot esculenta Crantz) dengan Berbagai Perlakuan terhadap Kadar $\beta$-Karoten. Indonesian Journal of Human Nutrition, Juni 2014, Volume 1 Edisi $1: 23$ - 34 . E-ISSN 23553987 www.ijhn.ub.ac.id

[2] Paendong F.T., Suparman E., Tendean H.M.M. The Profile of Maternal Anemia at The Primary Health Care Bahu Manado. Jurnal e-Clinic (eCl), Vol. 4, No. 1, Januari-Juni 2016.

[3] Munarso, S. J. dan B. Haryanto. Perkembangan Teknologi Pengolahan Mie. Prosiding Seminar Nasional dan Kongres Perhimpunan Ahli Teknologi Pangan Indonesia (PATPI). Hal. 566573. http://www.iptek.net.id/ind/pustaka_pangan /pdf/prosiding/ poster/PTP18_Bambanghar-pengolahan_mie_patpi.pdf . 2010

[4] Dziedzic, S.Z. \& M.W. Kearsley, The Technology of Starch Production. Handbook of Starch Hydrolysis Products and Their Derivatives, Blackie Academic and Professional, London, pp.1-25, 1995.

[5] Hatcher, D. W. Asian noodle processing. In G. Owens (Ed.), Cereals processing technology (pp. 131-157). Cambridge: Woodhead. 2001.
[6] Lala F.H., Susilo B., Komar N. Characteristics Test of Instant Noodles Made from Wheat Flour with Mocaf Substitution. Jurnal Bioproses Komoditas Tropis. ISSN 2338-4670. Vol. 1 No. 2, Agustus 2013. 11-20.

[7] Narain R. and Ilango V., Analysis of Iron Content of Selected Vegetarian Food Items in Dubai UAE. International Journal of Science, Environment and Technology, ISSN 2278-3687 (O) Vol. 4, No 3, 543 - 552. 2015

[8] Blois, M.S., Antioxidant determinations by the use of a stable free radical. Nat., 26: 1199-1200. 1958.

[9] Official Methods of Analysis. Association of Official. Analytical Chemists (AOAC). Ed. by Helrich, K. 15th Edition. 1990. ISBN 0-935584.42-0. Pub. AOAC Inc. Arlington. Virginia 22201. USA.

[10] Sukrat B. and Sirichotiyakul S. The prevalence and causes of anemia during pregnancy in Maharaj Nakorn Chiang Mai Hospital. J. Med. Assoc. Thai; 89 (Suppl 4):S142-146. 2006.

[11] Harper J.L., Iron Deficiency Anemia. http://emedicine. medscape. com/ article/ 202333-overview. Updated: Nov 07, 2015

[12] Fatimah, H. Pola Konsumsi dan Kadar Hemoglobin Pada Ibu Hamil Di Kabupaten Maros,Sulawesi Selatan. Makara,Kesehatan.;Vol. 15(1): 31-36. 2011.

[13] Susiloningtyas, I., Pemberian Zat Besi (Fe) dalam Kehamilan. Journal Unissula ISSN: 2252-729X , Vol 50. No 128. 2012. http://journal.unissula.ac.id/index.php/majalahilmiahsultanagung/ article/view/

[14] Martorell R, Ascencio M, Tacsan L, Alfaro T, Young MF, Addo OY, Dary O, Flores-Ayala R. Effectiveness Evaluation of the food fortification program of Costa Rica: impact on anemia prevalence and hemoglobin concentrations in women and children1-5. Am J Clin Nutr 101(1):210-7. 2015

[15] Direktorat Gizi Departemen Kesehatan RI. 1992. Daftar Komposisi Bahan Makanan. Penerbit Bhartara Karya Aksara, Jakarta

[16] Alsuhendra. Antiatherosclerosis capacity of zn-chlorophyll derivatives from cassava leaves (Manihot esculenta Crank) on experimental rabbit. Dissertations. DT - Agriculture Technology [363]. 2004. http://repository.ipb.ac.id/handle/123456789/41172.

[17] Novelina, Anggraini T. \& Hermansyah R. Production of Liquid Chlorophyll from The Leaves of Green Grass Jelly (Premna oblongifolia Merr.). International Journal on Advanced Science Engineering Information Technology. Vol. 5 No. 5, ISSN: 20885334. 2015

[18] Endo, Y., R. Usuki, dan Kaneda. Antioksidant effect of chlorophyll and pheophytin on the autoxidation of oils in the dark. II. The mechanism of antioxidative action of chlorophyll. JAOCS $62: 1387$ 1390. 1985.

[19] Tuty Anggraini, Novelina, Umar Limber and Riska Amelia. Antioxidant Activities of Some Red, Black and White Rice Cultivar from West Sumatra, Indonesia. Pakistan Journal of Nutrition ISSN 1680-5194. 14 (2): 112-117, 2015

[20] Hosikian A, Lim S, Halim R, Danquah MK. Chlorophyll Extraction from Microalgae: A Review on the Process Engineering. International Journal of Chemical Enginering. Handawi Publishing Corporation, 10 (1). pp. 1-11. 2010.

[21] Mardaningsih F, Andriani MAM, Kawiji. The Influence of Ethanol Concentration and Temperature of Spray Dryer for Chlorophyll Powder Characteristics of Alfalfa (Medicago sativa L.) by using Binder Maltodextrin. Jurnal Teknosains Pangan Vol 1 No 1. ISSN: 2302-0733. 2012. pp 110-117. (Avaliable online at www.ilmupangan.fp.uns.ac.id).

[22] Standar Nasional Indonesia. Syarat Mutu Mie Basah SNI 2987:2015 - Mi basah. Jakarta : Badan Standarisasi Nasional. 2015.

[23] Winarno, F. G. Kimia Pangan dan Gizi. Gramedia Jakarta. 2004. 